\title{
REVIEW Agroecology: Challenges and opportunities for farming in the
Anthropocene
}

\author{
Miguel A. Altieri, and Clara I. Nicholls
}

University of California, Berkeley, California 94720, USA.

\begin{abstract}
M.A. Altieri, and C.I. Nicholls. 2020. Agroecology: challenges and opportunities for farming in the Anthropocene. Int. J. Agric. Nat. Resour. 204-215. The multiple crises facing humanity at the onset of the Anthropocene are creating a moment in which agroecology acquires greater relevance as an alternative approach for meeting sustainable development goals and providing guidelines for the reconstruction of a post-COVID-19 agricultural system that is capable of minimizing future widespread disruptions of food supplies by pandemics and climate change by enhancing linkages between small-scale food production and local consumption. There are three main areas in which agroecology can be used in the development of a new post-COVID-19 agricultural system: revitalizing small farms, creating alternative animal production systems and enhancing urban agriculture. Focusing food and agricultural policies on agroecology as a main strategy for achieving autonomy and resilience can rapidly transform the ways in which we produce and consume food while addressing global challenges, including climate change, biodiversity loss, food insecurity, poverty, and deteriorating health.
\end{abstract}

Key words: Agroecology, COVID-19, food sovereignty, sustainable development goals, resilience.

\section{Introduction}

Humanity is facing a series of global problems: energy shortages, water scarcity, environmental degradation, biodiversity loss, climate change, economic inequality, food insecurity and others. These problems cannot be addressed in isolation, as they are systemic in nature; that is, they are interconnected and interdependent. When one of these problems is aggravated, the effects spread throughout the system, exacerbating the other problems (Capra \& Luisi, 2014). COVID-19 exemplifies how closely linked human, animal and ecological health are, providing lessons for improving environmental and human health by designing agricultural systems based on agroecological practices that minimize health risks to humans and ecosystems.

In this moment of ecological and economic crisis, the pandemic constitutes a manifestation of a cascade of catastrophes that willimpacthumanity as long as the economic model continues promoting extractive and consuming patterns. The rapid 
expansion of industrial agriculture and its disruption of wild ecosystems is part of this cascade, which imposes a great ecological toll on the planet, a trend that agroecologists contend must be reversed (Campbell et al., 2017). Agroecology points the way towards the restoration of ecological rationale in agriculture by promoting principles and practices that lead to more biodiverse agricultural systems that are more resilient topestoutbreaks, pandemics, climate disruptions, and other future shocks (Nicholls et al., 2016). A guiding principle in agroecology is to mimic natural ecosystems by reorganizing agroecosystems based on the principles of diversity, synergy, efficiency, and recycling (Gliessman, 2010). Inspired by the diverse models of traditional agriculture that have stood the test of time, agroecologists promote crop diversification (polycultures, rotations, agroforestry systems and crop-livestock-fish integration) as an effective agroecological strategy to reintroduce biodiversity into agroecosystems, which in turn provides a number of ecological services to farmers, such as soil fertility, pest and disease regulation, and pollination, while enhancing autonomy, resilience and food sovereignty (Nicholls et al., 2016). Agroecology also embraces a sociopolitical dimension, advocating for social justice and the radical transformation of the corporate-controlled food system (Rosset \& Altieri, 2017).

The COVID-19 pandemic has revealed the deficiencies of monocultures and confined animal operations, which generate dramatic biodiversity losses, public health deterioration, food waste, exploitation of migrant laborers, and the undermining of livelihoods of smallfarmers across the world. Given this grim reality, agroecology is the only available agricultural path in the Anthropocene, offering rural families environmental and socioeconomic benefits while providing urban populations with equitable and sustainable food provisioning (FAO, 2015). Agroecology is today a farmer-driven global movement backed by many sectors of civil society aimed at promoting food sovereignty, agrarian reform and the protection of rural land and its biodiversity (Giraldo \& Rosset, 2018). The ultimate goal of agroecology is to develop agroecosystems that support healthy ecosystems while providing a diverse mix of crops to enhance dietary diversity and human health, with the ultimate goal of creating equitable food systems.

This paper examines the potential of agroecology in addressing global challenges faced in the Anthropocene by analyzing the contributions of agroecology to the sustainable development goals (SDGs) and by examining three paths that agroecology offers for the reconstruction of a post-COVID-19.

\section{Agroecology and its contribution to the sustainable development goals}

Agroecology is linked to all the SDGs (Millenium Institute, 2018) and can contribute directly and indirectly to the advancement of each by providing technical and social strategies to reshape the world's food systems. Scientific evidence has shown that agroecology can increase crop yields and animal production and thus total farm output, increase the stability of production through diversification, enhance the resilience of farms to climate change, improve diets and income, conserve biodiversity and the natural resource base, and reduce farmer dependency on external inputs, all of which are essential ingredients for improving the livelihoods of smallholder farmers (Rosset \& Altieri, 2017).

In addition to increasing food production and other ecological benefits, agroecologically based multifunctional systems have many social and economic benefits, such as the diversification of income, the empowerment of women, greater autonomy among farmers and the ability of farmers to control their food production systems, thereby supporting the multiple environmental, social and economic dimensions of the SDGs (Figure 1). Clearly, applying agroecology to achieve the 
specific targets of most SDGs requires addressing environmental concerns (biodiversity, sustainable and resilient agricultural production, etc.), public health issues (hunger, malnutrition, etc.) and socioeconomic factors (farmers' income, markets, policies, etc.). The agroecological transdisciplinary approach is well equipped for such a systemic approach, as it integrates perspectives from ecology, agricultural sciences, nutrition, public health and political economics (Méndez, Bacon \& Cohen, 2013).

Figure 2 illustrates the complexity of the synergies that emerge when applying agroecological principles to design diversified farming systems aimed at addressing biological constraints, enhanced production, resilience, and biodiversity conservation while directly impacting SDG 2 (zero hunger) and SDG 13 (climate action).

\section{Agroecology and zero hunger (SDG 2)}

Zero hunger (SDG 2), has the objective of overcoming the complex food security challenges facing more than 815 million people who are undernourished and many more worldwide with problems accessing food. Achieving this goal is a challenge in the context of an industrial agricultural sector that globally covers more than 1.5 billion hectares, impacting critical ecosystem services on which crop production depends (Green et al., 2005).

Much has been written about the role of agriculture in achieving $\mathrm{SDG}_{2}$ (zero hunger). However, the majority of approaches focus too narrowly on increasing crop yields to overcome hunger (Godfray et al., 2010) and do not adequately consider the fact that hunger today is not due to low food production or to global supplies not meeting demand; rather, it is due to structural problems such as poverty, the maldistribution of food, food waste, lack of access to land and other aspects of the food system (Lappe, Collins $\&$ Rosset, 1998). A productivist view of hunger also fails to alter the tightly concentrated distribution of economic power that determines who can buy different foods or have access to seeds, breeding stock, knowledge, water and land for production. In turn, what is needed is to address the root causes of hunger and increase access to

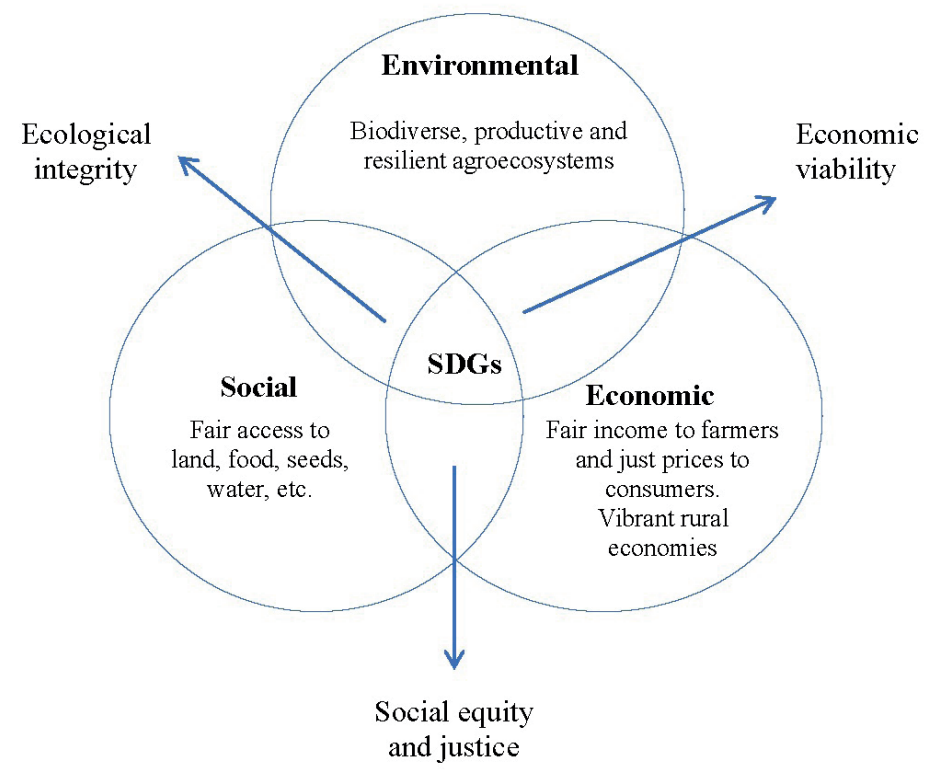

Figure 1. The role of agroecology in supporting the multiple dimensions of the sustainable development goals (SDGs). 


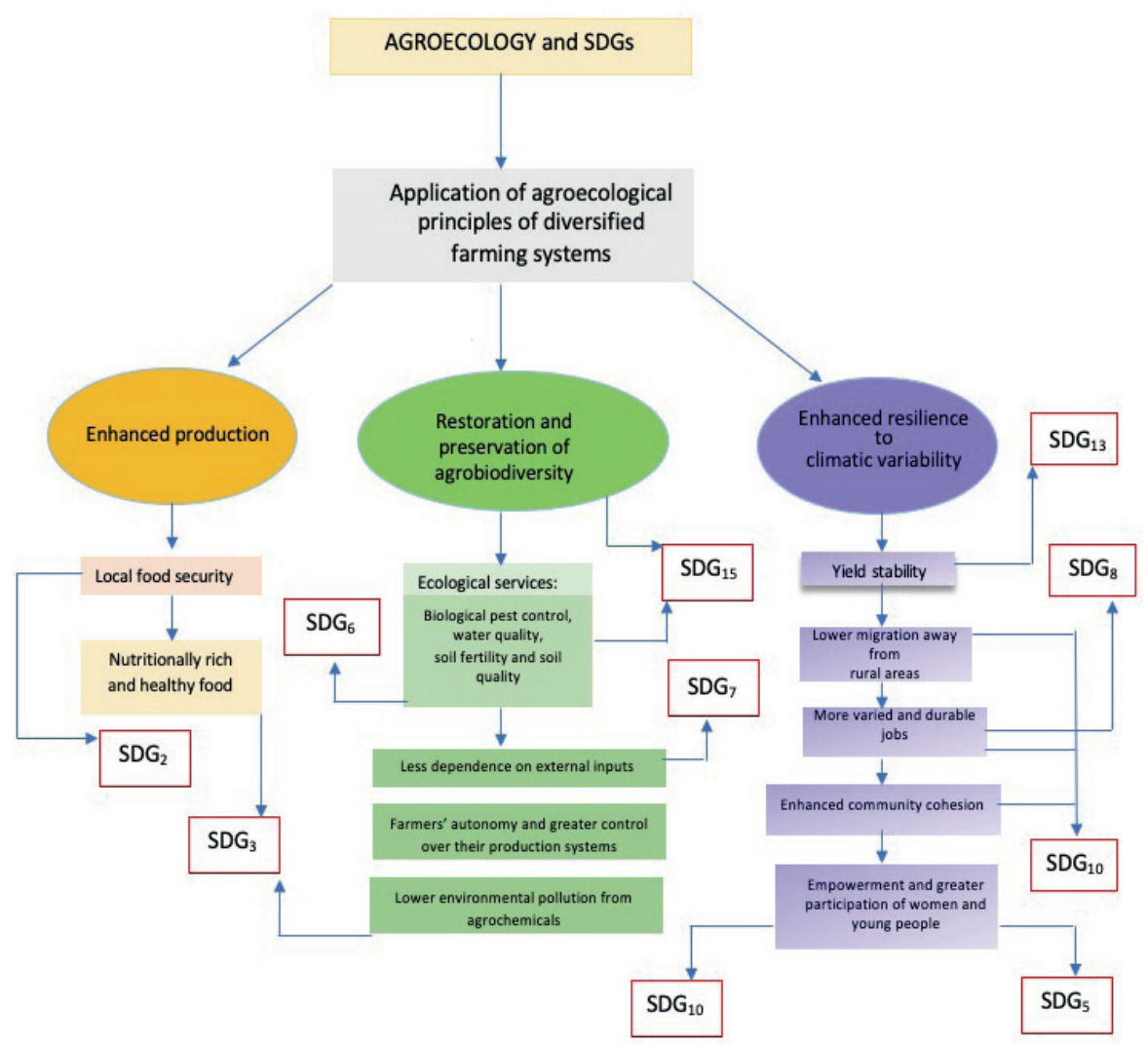

Figure 2. Agroecologically based diversified farming systems and synergies between outcomes and SDG targets.

healthy diets, land and income among the poorest segments of the population (Blesh et al., 2019). Transformative change can be achieved only by designing policies that ensure small farmers have secure access to land, water, seeds, and breeding stock to produce food based on agroecological practices and the ability to distribute diverse foods locally via local markets, thus making them accessible to all segments of urban and rural societies, in particular, people who are hungry and food insecure (Holt-Gimenez, 2019).

For agroecologists, it is clear that food security and biodiversity conservation are intimately connected, but in most international and national policy circles, they are perceived as competing goals. The dominant narrative focuses on doubling food production with minimal impact on ecosystems and associated biodiversity. Only agricultural approaches and technologies that hold transformative potential, such as agroecology, can address such false dichotomies (Perfecto et al., 2009). There are many agroecological initiatives that improve food security while contributing to biodiversity conservation and/or enhancement at the farm and landscape levels. Agroecological programs that revitalize traditional farming systems as the basis for local food security have been shown to maintain and even enhance regional agrobiodiversity (Perfecto et al., 2009). For example, in many countries (i.e., Brazil and Colombia), the removal of shade trees is encouraged to increase the production of new cocoa and coffee varieties, but such policies diminish smallholders' ability to adapt to global change as overall biodiversity decreases. Agroecology reduces such tradeoffs by providing ideas for adaptation strategies that combine vegetational diversification with innovative management practices, stabilizing cocoa and coffee yields while maintaining habitats for birds, bats, insects and other fauna and flora (Altieri, 2004). 
Case Studies on Agroecology and $S D G_{2}$

\section{The Philippines}

A project implemented by MASIPAG (a network of small-scale farmers, researchers, and members of nongovernmental organizations) compared the performances of a large group of organic farmers, farmers converting to organic agriculture and conventional farmers. The results from the evaluation revealed that compared to the other farmers, organic farmers improved their food security due to their higher on-farm diversity, growing approximately $50 \%$ more crops than conventional farmers. The diets of the organic farmers and their families were more diverse and nutritious; thus, they tended to enjoy better health. The organic farms exhibited better soil fertility, less soil erosion, and increased tolerance of crops to pests and diseases, apparently due to improved management practices. Overall, the results of this study showed that organic farming offers better options for the poorest people in rural areas, as it also requires less use of costly inputs, relying more on locally available resources (Bachmann et al., 2009).

\section{Chile}

During the 1990s, in various rural regions of Chile, the Centro de Educación y Tecnología (CET) promoted development programs designed to assist small farmers in achieving food self-sufficiency through the restoration of the productive capacity of small farms. CET technicians guided several farmers to establish several diversified 0.5 ha farms featuring combinations and rotations of forage and row crops, vegetables, and fruit trees, while integrating animals. Vegetable crops were grown in raised beds rich in organic matter, providing average yields of $83 \mathrm{~kg}$ of fresh vegetables per month. Other areas surrounding the house were used to plant a small orchard and to raise cows, hens, rabbits, and bees. The rest of the half hectare was devoted to a six-year rotation that produced vegetables, cereals, legumes, and forage crops.
The rotation allowed farmers to grow 13 different crop species, which produced approximately 6 tons/year (Altieri, 1999).

Fruit trees were planted as hedgerows, producing more than 1 ton of fruits. Milk and egg production were also high. A nutritional analysis of the system showed that after a family of five fed itself, the farm produced a significant surplus of protein, vitamin A and C, and calcium. The family bought few food items in the market, and the selling of the food surpluses provided a net income of US $\$ 790$ while dedicating only relatively few hours per week to the farm. The free time gained was used by farmers for activities that added value to their production, such as making cheese and marmalades that could be sold, or engaging in other off-farm income-generating activities (Altieri, 2002).

\section{Agroecology and Climate action (SDG 13)}

The connection between agroecology and $\mathrm{SDG}_{13}$ lies in the potential of agroecology to enhance the adaptation capacity of agroecosystems to climate change. Agroecological design emphasizes the enhancement of farming system complexity through various spatiotemporal plant and animal combinations, which enhances adaptability to extreme climatic events. Agroecosystems tend to exhibit higher resilience when they are surrounded by complex vegetation and feature diverse cropping designs, organic matter-rich soils and water conservation practices (Altieri et al., 2015).

\section{Case Studies on Agroecology and $S D G_{13}$}

\section{Central America and Cuba}

Studies conducted after Hurricane Mitch showed that hillside farmers using cover crops, intercropping, and agroforestry schemes experienced lower soil erosion and mudslides than their conventional 
counterparts. A survey of 360 rural communities in Nicaragua, Honduras, and Guatemala, consisting of paired observations of neighboring agroecological and conventional farms, found that the agroecological farms lost 20 to $40 \%$ less topsoil through erosion, thus experiencing lower economic losses than the conventional farms (Holt-Gimenez, 2002). Researchers conducted a farm survey in the provinces of Holguin and Las Tunas 40 days after Hurricane Ike hit that region of Cuba and reported 50\% less losses from diversified farms than from neighboring monocultures. In fact, farms based on agroecological principles tended to exhibit a faster productive recovery than farms based on monocultures (Rosset et al., 2011).

\section{Colombia}

Intensive silvopastoral systems are a type of agroforestry system in which livestock production occurs in pastures that include forage grasses, fodder shrubs, trees and palms. In these systems, rotational grazing and a permanent supply of water for cattle are key to achieving high animal stocking rates and reliable production of milk and meat. El Hatico farm in the Valle del Cauca, Colombia, features a multilayered silvopastoral design with grasses, Leucaena shrubs, mediumsized trees, and sparse larger trees. At El Hatico, stocking rates reach 4.3 dairy cows ha- ${ }^{-1}$ and milk production remains constant at approximately 10-12 liters per animal per day without the use of chemical fertilizers. 2009 was a very dry year; although pasture production decreased by $25 \%$, tree and shrub forage production remained constant, thus maintaining farm milk production, while other farmers in the region reported high animal mortality rates due to a lack of food and water. The performance of El Hatico during extremely hot and dry spells illustrates the potential of silvopastoral systems as a strategy for adapting to climate change. Resilience in these systems is linked to water retention and regulation, favorable microclimates, enhanced carbon stocks and vegetational complexity (Murgueitio et al., 2011).

\section{Agroecology in times of COVID-19}

As a result of the COVID-19 pandemic, farms' production practices have been affected by a lack of labor and food distribution has been affected by disrupted supply chains, which have led to food shortages, especially among increasingly poor and unemployed populations. The fragility of the globalized food system has become apparent, and there is a need for a transition to a more socially just, ecologically resilient, and localized food system. Agroecology can help in such transitions by promoting diversified and resilient agroecosystems that produce healthy food while delivering ecosystem services (Nicholls, Altieri \& Vazquez, 2016). Agroecology is already providing solutions to some of the new food and agricultural challenges emerging from the pandemic (Altieri \& Nicholls, 2020), particularly by strengthening action on optimizing urban agriculture, promoting alternative animal production systems and revitalizing farm and family agriculture (Figure 3).

\section{Revitalizing small farms and family agriculture}

The basis for the new agricultural systems that humanity needs in the Anthropocene is the myriad of ecologically based agricultural practices inherited and/or developed by farmers, family farmers and indigenous people, mostly in developing countries. By combining traditional agricultural knowledge and modern ecology and agronomic sciences, agroecology provides principles and practices to restore the productivity of small farms by enhancing plant health and soil quality. The application of agroecological principles leads to the design of biodiverse farms with stable crop yields, generating income and dietary diversity, thus improving the nutrition of rural families (Altieri, 1999; Pretty, Morrison \& Hine, 2003; IPES, 2016). 


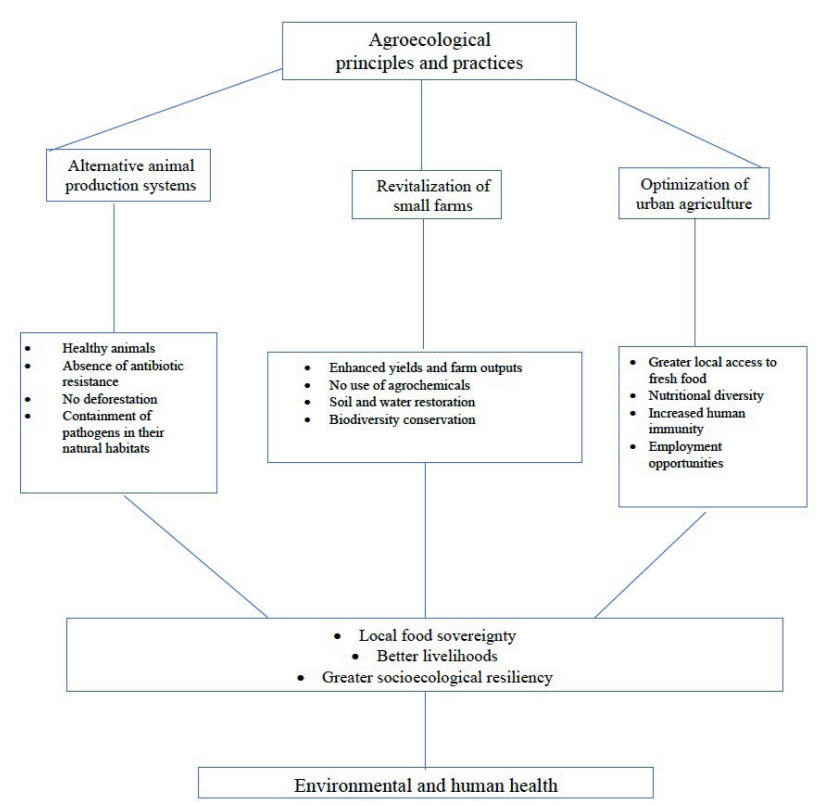

Figure 3. Contributions of agroecology to a healthy agriculture post-COVID-19.

Thousands of isolated experiences around the world have demonstrated that agroecology can be used to produce abundant healthy food while conserving soil, water, and biodiversity. Assessments of hundreds of agroecological initiatives promoted by many organizations in Africa, Asia and Latin America have shown that using agroecology, traditional farming systems can be redesigned to increase yields using labor and local resources more efficiently (Rosset \& Altieri, 2017). In Latin America, evaluations conducted among more than 100,000 farming families/units revealed that agroecological practices can increase crop yields from 400-600 to 2,000-2,500 $\mathrm{kg} \mathrm{ha}^{-1}$ while conserving agrobiodiversity and its effects on food security and environmental quality. Green manures, cover crops and mulching increase corn yields in marginal environments from $1-1.5 \mathrm{t}$ per ha- $4 \mathrm{t}$ per ha. This is significant in a region where small-scale farms produce between 50 and $70 \%$ of the domestic food but control only $30 \%$ of the arable land (ETC, 2017). In countries such as Cuba, smallholder farmers using agroecological methods can feed 20 people per year with the yields obtained from one hectare (Rosset et al., 2011, Funes \& Vazquez, 2016).

\section{Alternative animal production systems}

As described above, silvopastoral systems comprise alternative livestock production systems designed with agroecological principles. These systems create complex habitats that support diverse plants and grazing animals, where trees and palms provide wood products as well as fruits, seeds, and pods for cattle food. Leguminous trees also improve soil fertility through nitrogen fixation by uptaking nutrients from deeper soil horizons, accumulating litter and replenishing and recycling organic matter and soil nutrients (Murgueitio et al., 2011).

Animals raised in silvopastoral systems are healthy and tend to be less susceptible to diseases. Furthermore, animals that live outdoors and feed on natural vegetation exhibit strong immune systems; therefore, the need for antibiotics is rare. Animals are rotated in silvopastoral systems, increasing stocking rates per hectare and sustaining milk production per animal (Murgueitio et al., 2015).

Silvopastoral systems restore landscapes and do not expand at the expense of natural habitats, 
as is the case with conventional cattle ranching, a process that exacerbates risks by amplifying human-wildlife interactions, thus increasing possibilities for disease emergence. By avoiding deforestation, silvopastoral systems avoid triggering the spillover of pathogens contained in their natural habitats into livestock and human communities (Wallace, 2016).

\section{Enhancing urban agriculture}

As COVID-19 fractures the existing food supply chains, an increasing number of urban inhabitants who rely on food sourced from remote farms are turning to urban agriculture as a source of fresh food. Around the world, urban farming has experienced a sharp increase, and many cities derive approximately $30 \%$ of their fresh vegetables from urban gardens. With proper implementation, urban farming could be a major avenue to bridge some of the food gaps by promoting the production of fresh fruits, vegetables, and eggs near consumers, thus improving local food security and nutrition, particularly in poorer communities (Zezza, \& Tasciotti, 2010). In addition, urban agriculture can create much needed jobs among the increasingly unemployed population.

The same agroecological principles used in rural areas can be applied in the design of highly diverse yet productive urban farms. Practices that follow agroecological principles, such as intercropping, cover crops, and composting, lead to better nutrient cycling and organic matter turnover for soil fertility as well as water and soil conservation and enhanced regulation of pests - all key processes that determine optimal crop production in urban environments (Altieri \& Nicholls, 2018). In Cuba, most urban farms produce between 15 and $20 \mathrm{~kg}$ $\mathrm{m}^{-2}$ year ${ }^{-1}$ of food (Funes \& Vazquez, 2016). In central Chile, Infante (1986) designed an $11.05 \mathrm{~m}^{2}$ urban garden with 16 crop species that produced approximately $16 \mathrm{~kg} \mathrm{~m}^{-2}$ year ${ }^{-1}$ of vegetables. Examples from Cuba and Chile demonstrate the potential for using agroecological principles to achieve intense cultivation of vegetables, legumes, roots and tubers, and herbs in small spaces.

Well-managed urban farms can be up to 15 times more productive than farms located in rural areas, as one intensively cultivated square meter of soil can produce up to $20 \mathrm{~kg}$ of food per year. Not only can a $10 \mathrm{~m}^{2}$ bed meet the $72 \mathrm{~kg}_{\text {year }}{ }^{1}$ vegetable requirements of one person, but its 200 $\mathrm{kg}$ production of vegetables per year provides $55 \%$ of the yearly vegetable needs of a family of five (Koont, 2011).

Urban agriculture enhances the ability of households to access locally produced food, thus improving the nutrition of families through more diverse diets. In this time of crisis, urban food production is expanding as more people realize that production and access to locally produced food is of strategic importance. In addition, increased dietary nutrient intake may improve the immune system, and there is evidence that a plant-based diet could help people enhance their defenses against viruses (Aman \& Masood, 2020).

\section{Conclusions}

There is a consensus that the predominant ways food is produced and consumed urgently need to change to address global challenges such as climate change, biodiversity loss, poverty, and deteriorating health. Investing in agroecology as a strategic pathway for agricultural development is key to addressing such challenges and simultaneously achieving various SDGs. Agroecologically oriented programs and initiatives exhibit great potential in reducing poverty; enhancing food security at the local level; conserving and utilizing biodiversity to strengthen ecosystem services; restoring soil and water resources; divorcing farms from their dependence on agrochemicals, imported feed and fossil fuels; and enhancing the resilience of farming systems to climate change (Gliessman, 2010). Agroecologically managed agroecosystems do not depend on external inputs such as agro- 
chemicals; instead, biodiverse agroecosystems rely on synergies among farm components that lead to soil fertility and pest/disease regulation and other essential ecosystem services. Farms redesigned based on agroecological principles provide the foundation for farming communities to reach autonomy and food sovereignty (Altieri, 2002).

The COVID-19 crisis provides new opportunities for agroecologists to explore adaptive responses to the pandemic by designing more resilient and sustainable food systems that rely on vegetable gardens at homes and schools, the revitalization of small farms and innovative ways to shorten distances between producers and consumers. A main lesson of the pandemic is that food production needs to be placed under the responsibility of small-scale farmers, family farmers and urban farmers, who produce between 50 and $70 \%$ of the food consumed by most people (ETC, 2017). This is a key path to ensure the supply of fresh food at affordable prices in local markets, away from the global food chains (IPES, 2020). This reorganization of the food system should emphasize the creation of short supply chains and the provision of land, seeds, water and other production resources to rural and urban farmers so that they can continue producing food for local communities and improving household nutrition while generating income. Consumers should be made aware that by eating, they are committing an ecological and political act, and that by supporting local farmers, they are engaging in promoting socioecological sustainability and resilience.

The scaling up of agroecology requires major changes in policies, institutions, research, and development agendas to ensure that agroecological alternatives are adopted widely and are broadly accessible. Learning from hundreds of local and dispersed successful agroecological initiatives around the world can provide lessons on how to "amplify" agroecology to thousands of farming families in various territories, integrating prac- tice and science at the farm and landscape levels (Nicholls \& Altieri, 2018).

The development of equitable local and regional markets where farm products are sold at fair prices is key to enhancing the economic viability of agroecological initiatives. Similarly, innovative policies are needed to support the agroecological transition and the broad adoption of agroecological strategies. In particular, new public policies are required to strengthen the role of family farmers' organizations in regulating agri-food systems and territorial development.

The transition to agroecological practices can lead to more socially just, economically viable and environmentally sound agriculture but requires alliances between rural and urban social movements that are committed to supporting the goals of these farmers' movements, including the rapid dissemination of agroecology among thousands of farmers (Levidow, Pimbert \& Vanloqueren, 2014). Pedagogical and extension models, such as Campesino a Campesino, in which farmers, women and young people actively participate in a process of local technological innovation, sharing experiences to enhance capacities to solve pressing problems, are fundamental.

The crisis that unfolded because of the COVID-19 pandemic adds momentum to the food movement that for years has challenged the industrial agriculture model, advocating for a transition towards more equitable food systems. Transformational change in agriculture involves changes in other sectors of the economy and society, such as shifts from a market economy to a solidarity economy, from petroleum to alternative forms of renewable energy, and from a corporate-controlled food system to one mediated by cooperatives. Many people foresee a new post-COVID-19 world led by allied social, urban, and rural movements convinced that a return to the way agriculture was practiced before the pandemic is not desirable. Instead, what they propose is to turn agroecologically based urban and rural farms into a vital asset or 
humankind patrimony that provides healthy and accessible food while consolidating sustainable and healthy agroecological territories.

\section{Acknowledgements}

This manuscript summarises the authors' intended contribution at the Workshop on Challenges for Agroecology Development for the Building of Sustainable Agri-Food Systems (CRP), which was due to take place at the Faculty of Agricultural Sciences, University of Chile, Santiago de Chile, on 11-13 November 2019, and which was sponsored by the OECD Co-operative Research Programme: Biological Resource Management for Sustainable Agricultural Systems. Although due to the circumstances the workshop did not take place as a physical meeting and contributions intended to be supported by the OECD CRP are published in this Thematic Issue.

\section{Disclaimer}

The opinions expressed and arguments employed in this manuscript are the sole responsibility of the authors and do not necessarily reflect those of the OECD or of the governments of its Member countries.

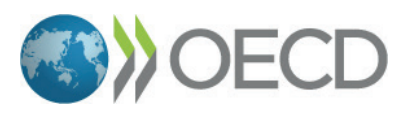

\title{
Resumen
}

\begin{abstract}
M.A. Altieri, y C.I. Nicholls. 2020. Agroecología: desafíos y oportunidades para cultivar en el Antropoceno. Int. J. Agric. Nat. Resour. 204-215. Las múltiples crisis que enfrenta la humanidad al inicio del Antropoceno, estan creando un momento en que la agroecología adquiere cada vez más relevancia. Como una alternativa para alcanzar los Objetivos del Milenio para el Desarrollo y para decifrar un sendero para reconstruir una agricultura post COVID 19, capaz de evitar disrupciones futuras en la alimentación al territorializar la producción campesina y el consumo local. Hay tres áreas claves en las que la agroecología puede señalar el camino hacia una nueva agricultura post COVID-19: revitalizar las pequeñas granjas, crear sistemas alternativos de producción animal y mejorar la agricultura urbana. Enfocar las políticas agrícolas y alimentarias en la agroecología como una estrategia clave para alcanzar la autonomía y resiliencia puede rápidamente transformar la manera como se produce y consume alimentos, a la vez que se confrontan los desafíos asociados al cambio climático, pérdida de biodiversidad, pobreza, inseguridad alimentaria y empeoramiento de la salud.
\end{abstract}

Palabras claves: Agroecología, COVID-19, objetivos del desarrollo sostenible, resiliencia, soberanía alimentaria.

\section{References}

Altieri, M.A. (1999). Applying agroecology to enhance productivity of peasant farming systems in Latin America. Environment, Development and Sustainability 1:197-217.

Altieri, M.A. (2002). Agroecology: the science of natural resource management for poor farmers in marginal environments. Agriculture, Ecosystems and Environment 93:1-24 doi: 10.1016/S01678809(02)00085-3

Altieri, M.A. (2004). Agroecology versus Ecoagriculture: Balancing Food Production and Biodiversity Conservation in the Midst of Social Inequity. CEESP Occasional Papers \# 3. Tehran: CENESTA IUCN Commission on Environmental, Economic and Social Policy (CEESP). 
Altieri, M.A., Nicholls, C.I., Henao, A., \& Lana, M.A. (2015). Agroecology and the design of climate change-resilient farming systems. Agronomy for Sustainable Development 35:869-890.

Altieri, M.A. \& Nicholls, C.I. (2018). Urban agroecology: designing biodiverse, productive and resilient city farms. AgroSur 46:49-60.

Altieri, M.A. \& Nicholls, C.I. (2020). Agroecology and the reconstruction of a post-COVID-19 agriculture, The Journal of Peasant Studies, 47:881898. doi: 10.1080/03066150.2020.1782891

Aman F., \& Masood S. (2020). How Nutrition can help to fight against COVID-19 Pandemic. Pakistan Journal of Medical Sciences, 36(COVID19S4): COVID19-S121-S123. doi: 10.12669/ pjms.36.COVID19-S4.2776

Bachmann, L., Cruzada, R., \& Wright, S. (2009). A study of the impacts of farmer-led sustainable agriculture in the Philippines. Masipag-Misereor, Los Baños.

Blesh, J., Hoey, L., Jones, A.D., Friedmann, H., \& Perfecto, I. (2019). Development pathways toward Zero Hunger. World Development, 118:114.

Campbell, B.M., Beare, D.J., Bennett, E.M., HallSpencer, J.M, Ingram, J.S.I., Jaramillo, F., Ortiz, R., Ramankutty, N., Sayer, J.A., \& Shindell, D. (2017). Agriculture Production as a Major Driver of the Earth System Exceeding Planetary Boundaries. Ecology and Society, 22(4):8. doi: 10.5751/ ES- 09595-220408

Capra, F., \& Luisi, P.L. (2014). The systems view of life: a unifying vision. Cambridge University Press, Cambridge.

ETC Group. (2017). Who will feed us? The Peasant Food Web vs. the Industrial Food Chain. Retrieved from www.etcgroup.org/whowillfeedus.

FAO. (2015). Agroecology for Food Security and Nutrition. Retrieved from http://www.fao.org/3/ a-i4729e.pdf

Funes, F.A., \& Vázquez, L.L. (2016). Avances de la Agroecologia en Cuba. Estacion Experimental de Pastos y Forrajes Indio Hatuey, Matanzas, Cuba.

Giraldo, O.F., \& Rosset, P. (2018). Agroecology and a territory in dispute: between institutionality and social movements. Journal of Peasant Studies, 45(3):545-564.

Gliessman, S.R. (2010). Agroecology: The Ecology of Sustainable Food Systems, 2nd ed.; CRC Press: Boca Raton, FL, USA.

Godfray, H.C.J., Beddington, J.R., Crute, I.R., Haddad, L., Lawrence, D., Muir, J.F., Pretty, J., Robinson, S., Thomas, S.M., \& Toulmin, C. (2010). Food security: the challenge of feeding 9 billion people. Science, 327:812-818. doi: 10.1126/science. 1185383

Green, R.E., Cornell, S.J., Scharlemann, J.P.W, \& Balmford, A. (2005). Farming and the fate of wild nature. Science, 307:550-555. doi: 10.1126/ science. 1106049

Holt-Gimenez, E. (2002). Measuring farmers' agroecological resistance after Hurricane Mitch in Nicaragua: A case study in participatory, sustainable land management impact monitoring. $A g$ riculture, Ecosystems and Environment, 93:87105. doi: 10.1016/S0167-8809(02)00006-3

Holt-Gimenez, E. (2019). How to feed the world without destroying it. Polity, Oxford

Infante, A. L. (1986). Descripción de un sistema de producción intensivo de hortalizas a nivel familiar bajo tecnología orgánica (Tesis para optar a Ingeniero Agronomo. Universidad de Chile. Facultad de ciencias Agrarias y Forestales). Santiago, $178 \mathrm{p}$.

IPES-FOOD. (2016). From uniformity to diversity. Retrieved from http://www.ipes-food.org/_img/ upload/files/UniformityToDiversity_FULL.pdf

IPES-FOOD. (2020). COVID-19 and the crisis in food systems: Symptoms, causes, and potential solutions. Retrieved from http://www.ipes-food. org/_img/upload/files/COVID-19_CommuniqueEN.pdf

Koont, S. (2011). Sustainable urban agriculture in Cuba. Springer, Berlin.

Lappe, F.M., Collins, J., \& Rosset, P. (1998). World Hunger: Twelve Myths. 2nd ed. New York: Grove Press.

Levidow, L., Pimbert, M., \& Vanloqueren, G. (2014). Agroecological research: Conforming- or transforming the dominant agrofood regime? Agroecology and Sustain- 
able Food Systems, 38(10):1127-55. doi: 10.1080/21683565.2014.951459.

Masood, A.F, \& Aman, S. (2020). How Nutrition can help to fight against COVID-19 Pandemic. Pak $J$ Med Sci, 36(COVID19-S4):COVID19-S121S123. doi: 10.12669/pjms.36.COVID19-S4.2776

Méndez, V.E., Bacon, C.M., \& Cohen, R. (2013). Agroecology as a transdisciplinary, participatory, and action-oriented approach. Agroecology and Sustainable Food Systems, 37(1):3-18. doi: 10.1080/10440046.2012.736926.

Millenium Institute. (2018). The impact of agroecology on the achievement of the Sustainable Development Goals (SDGs). An integrated scenario analysis. BioVision Foundation.

Murgueitio, E., Calle, Z., Uribea, F., Calle, A., \& Solorio, B. (2011). Native trees and shrubs for the productive rehabilitation of tropical cattle ranching lands. Forest Ecology and Management, 261:1654-1663. doi 10.1016/j.foreco.2010.09.027

Murgueitio, E., Flores, M., Calle, Z., Chará, J., Barahona, R., Molina, C., \& Uribe, F. (2015). Productividad en Sistemas Silvopastoriles Intensivos en América Latina. In F. Montagnini, E. Somarriba, E. Murgueitio, H. Fassola, \& B. Eibl (Eds), Sistemas Agroforestales. Funciones Productivas, Socioeconómicas y Ambientales. Serie Técnica Informe Técnico 402 (pp. 59-101), CATIE, Turrialba, Costa Rica, Cali: Fundación CIPAV.
Nicholls, C.I., \& Altieri, M.A. (2018). Pathways for the amplification of agroecology. Agroecology and Sustainable Food Systems, 42:10-23.

Nicholls, C.I., Altieri, M.A., \& Vazquez, L. (2016). Principles for the Conversion and Redesign of Farming Systems. Journal of Ecology and Ecography, S5:10. doi: 10.4127/2157-7265-S5-010.

Perfecto, I., Vandermeer, J., \& Wright, A. (2009). Nature's Matrix: Linking Agriculture, Conservation and Food Sovereignty. London: Earthscan. 272p.

Pretty, J., Morrison, J.I.L., \& Hine, R.E. (2003). Reducing Food Poverty by Increasing Agricultural. Sustainability in Developing Countries." Agriculture, Ecosystems and Environment, 95:217-234.

Rosset, P.M., Machín-Sosa, B., Roque-Jaime, A.M, \& Avila-Lozano, D.R. (2011). The Campesinoto-Campesino agroecology movement of ANAP in Cuba. Journal of Peasant Studies, 38(1):16191. doi: 10.1080/03066150.2010.538584

Rosset, P.M., \& Altieri, M.A. (2017). Agroecology: Science and Politics. Fernwood Publishing. Nova Scotia, Canada.

Wallace, R. (2016). Big Farms Make Big Flu: Dispatches on Infectious Disease, Agribusiness, and the Nature of Science. New York: NYU Press.

Zezza, A., Tasciotti, L., (2010). Urban Agriculture, Poverty, and Food Security: Empirical Evidence from a Sample of Developing Countries. Food Policy, 35:265-273. 